\title{
Med Pinocchio i skole
}

\section{Om udvikling af den professionelle dømmekraft i undersøgelsesfællesskaber}

\author{
Kirsten M. Andersen, lektor, UC Syd, kman@ucsyd.dk \\ Rasmus Aaskov Iversen, adjunkt, UC Syd, raiv@ucsyd.dk \\ Robert Eskildsen Jepsen, lektor, UC Syd, rjep@ucsyd.dk \\ Max Ipsen, lektor, UC Syd, mips@ucsyd.dk
}

\begin{abstract}
Resumé
Med udgangspunkt i de politiske ønsker om en læreruddannelse, der har mere praksis, analyseres og diskuteres, hvordan praksis kan kvalificeres. Artiklen indledes med en påstand om, at en studiemæssig kvalificering af praksis ikke skal drives på afveje af akademisering, men udfordres af høj faglighed i pædagogik, fag og akademiske dyder.

Herfra argumenterer vi for et perspektivskifte i forståelsen af praksis, hvor det centrale er reflekteret arbejde med fokuseret empiri og udvikling af den studerendes dømmekraft. Med udgangspunkt i fænomenet kernepraksis gøres fokuseret empiri til "kernen" i perspektivskiftet. Vi har valgt at fremhæve et eksempel fra praksis for at argumentere for, at en dialektisk omgang med empiri skaber en reflekterende sammentænkning af teori og praksis. Den dialektiske arbejdsform er kendetegnet ved at være dynamisk og ved, at den udfordrer de studerendes dømmekraft ved at bringe viden, didaktik og erfaring i spil i forhold til den fokuserede empiri.

Afslutningsvis foreslår vi etablering af undersøgelsesfællesskaber som rammesættende for et rum, hvor refleksion og dømmekraft kan faciliteres. I disse fællesskaber skaber teori og praksis mulighed for at kvalificere empirien og dermed den studerendes praksis og faglige refleksion. Endelig konkretiseres fokuseret empiri, som det kan tage form i et reflekteret undersøgelsesfællesskab.
\end{abstract}

Nøgleord: kernepraksis, dialektik, dømmekraft, undersøgelsesfællesskaber

\begin{abstract}
Starting from the political wish for a teacher education with more practice, it is analyzed and discussed, how practice may be qualified. The article begins with the claim that qualifying teacher study academically must not be driven astray by academicization, but rather challenged by professionalism and knowledge when it comes to pedagogy, subject, and academic virtues.

We argue for a change of perspective in the understanding of practice, where the core is reflected work with focused empirics, developing the judgment of the students.

With the phenomenon of core practice focused empirics becomes the "core" in the change of perspective, and with a case we argue for a dialectic as a reflected co-thinking of theory and practice. A dialectic approach involves complex thinking, which may challenge the students' judgment by bringing knowledge, didactic and experience in relation to the focused empirics.
\end{abstract}


Thus, we suggest establishing research communities as a frame, for facilitating reflection and judgment. In these communities it is possible by theory and practice to qualify the empirics and thus the practice and professional reflection of the students. Concluding it is concretized how focused empirics can appear in a research community.

Keywords: core practices, dialectic, judgement, research community

\section{Ud i virkeligheden}

I pressemeddelelsen "Læreruddannelsen skal tættere på praksis" lancerede uddannelses- og forskningsminister Ane Halsboe-Jørgensen i august 2020 regeringens målsætning om at sikre et højt ambitionsniveau for læreruddannelsen gennem "mere praksis, ikke [...] mere akademisering" (UFM, Læreruddannelsen skal tættere på praksis, 2020). Med formuleringen stiller Ane Halsboe-Jørgensen en modsætning op mellem praksis og akademisering.

Modsætningen, der bliver opstillet, er problematisk, og argumentet, der ligger bag, har stråmandskarakter. Ordet akademisering bærer en indbygget negativitet i sig. Akademisering betyder ifølge Den Danske Ordbog "det at gøre (unødig) akademisk; det at give et (for) teoretisk og formelt præg". Ingen kan ønske at gøre noget - heller ikke læreruddannelsen - unødig akademisk eller give noget et for teoretisk præg. Ordet henter uden nærmere bestemmelse betydning i ønsket om mere praksis, og det implicerer en afstandtagen til viden, der er abstrakt og uden forbindelse til skolens undervisning. En anden pressemeddelelse, "Minister sætter gang i arbejdet med at udvikle læreruddannelsen", bestyrker denne antagelse. Her hedder det nemlig, at "Læreruddannelsen skal endnu tættere på virkeligheden i klasselokalerne", og regeringen "ønsker derfor [...] at der kommer mere praksis ind i læreruddannelsen" (UFM, Minister sætter gang i arbejdet med at udvikle læreruddannelsen, 2020). Overvejelserne munder ud i formuleringen af tre overordnede temaer. Det første tema er "Styrket praktik og praksissamarbejde". I det underliggende notat, "Nytænkning af læreruddannelsen - et ambitiøst udviklingsarbejde", uddybes temaet. Praktik og praksissamarbejde skal styrkes, og det skal blandt andet ske ved, at de "lærerstuderende skal klædes bedre på til at træde ud i virkeligheden i folkeskolen", fx ved at de møder "mere virkelighedsnære praktikforløb" (UFM, Nytænkning af læreruddannelsen, 2020). 
Pointen, at afstanden mellem teori og praksis er for stor, og at den er et problem, kan forekomme forceret. På baggrund af et ønske om at gøre afstanden mellem teori og praksis mindre, har vi gennem de senere år set en udvikling mod praksisnær forskning. Spørgsmålet er, om det er den rette vej - eller måske rettere den eneste - vej at gå? Vores ambition i artiklen er at give et bud på, hvordan man kan udvikle praksis og læreruddannelse uden at opstille forcerede dikotomier, men ved netop at insistere på, at ikke alt er ens eller det samme, og at der i den dialektiske spænding, der kan opstå i og mellem det, der er forskelligt, kan ligge et potentiale. Hvis vi formår at tænke forholdet dialektisk og refleksivt, kan forskelligheden gøres til en styrke i stedet for en ufrugtbar modsætning mellem skolens virkelighed og læreruddannelsens (u)virkelighed.

Alexander von Oettingen har beskrevet forholdet mellem viden om skolen og den pædagogiske handlen således: "Aldrig har vi forsket så meget i læring, didaktik, digitale medier, inklusion, nye læringsformer etc., og aldrig før har vi haft så mange empiriske data og informationer til rådighed. Alligevel har vi svært ved at se, hvordan den empiriske viden transformeres til pædagogiske og didaktiske teorier, og hvad det betyder for praksis" (Oettingen, 2018, s. 19). Viden og handling bliver ikke bragt i forbindelse med hinanden.

Forholdet mellem teori og praksis, mellem viden og handling, er konstituerende for lærerens opgaver i skolen. Derfor skal forholdet ikke opløses, men være afsæt for refleksion. Der er ikke nødvendigvis brug for mere praksis i læreruddannelsen, men for en fokuseret og reflekteret omgang med praksis - også med et akademisk udgangspunkt. I en ganske anden sammenhæng har C. Y. Frostholm i Træmuseet mindet os om, at "Ikke alting er modsætninger. Ikke alting er så enkelt" (Frostholm, 2018, s. 234). Hvis alting var modsætninger, drejede det sig blot om at vælge den rigtige side i den opstillede modsætning: mere praksis, ikke mere akademisering. Så enkelt er det ikke, og vi er derfor nødt til at fastholde problemet i sin kompleksitet, i sin dialektik, og det gør vi, når vi argumenterer for bedre, ikke nødvendigvis mere, praksis, og når vi stiller spørgsmålet om, hvordan vi kan forbedre de eksisterende praksismuligheder i læreruddannelsen og inddrage disse i studiet til lærer. En kvalificering af praksis skal ikke drives på afveje af akademisering. Den skal udfordres af faglighed og akademiske dyder. Det kan man fx gøre ved, at man kvalificerer omgangen med de erfaringer og den empiri, som de lærerstuderende indsamler, erfarer og får kendskab til gennem praksisforskning undervejs i deres studium, og rette dem tilbage i 
praksis (Benner, 1980). Hvis vi i læreruddannelsen vælger at arbejde fokuseret med empiri som en aktivitet, der i dialektisk forstand skaber syntese mellem teori og praksis, kan vi måske styrke de studerendes læreprocesser med henblik på i sidste ende at kvalificere og udvikle undervisningen i folkeskolen.

Vi vil argumentere for og give eksempler på, hvordan en fokuseret og reflekteret omgang med empiri åbner op for et kernefokus, sans for muligheder for perspektivskifte og bevidste didaktiske justeringer. Vi mener med andre ord, at reflekteret arbejde med empiri kan bidrage til at forbedre den studerendes og lærernes professionelle dømmekraft og handlekompetence i praksis.

Artiklen inddrager situationer fra skolen, og vi forholder os i den til national og international forskning for gennem denne forskning og vores erfaringer med læreruddannelse, praksissamarbejde og praktik at komme med nogle teoretisk funderede bud på en retning for praktik, praksissamarbejde og for forholdet mellem praksis og teori.

\section{Professionel dømmekraft}

Den professionelle dømmekraft er i de senere år blevet fremdraget i forhold til lærerens arbejde i folkeskolen. Danmarks Lærerforening har fremhævet den professionelle dømmekraft i Folkeskoleidealet. Heri hedder det: "I folkeskolen har lærerne på baggrund af deres faglighed og professionelle dømmekraft ansvaret for skolens undervisning og dannelsesopgave samt at bidrage til folkeskolens udvikling", og i udlægningen af dette ideal: "Udgangspunktet for god undervisning er lærernes professionelle dømmekraft og engagement" (Danmarks Lærerforenings folkeskoleideal, 2021). I Professionsideal for Danmarks Lærerforening fremhæver man også lærerens dømmekraft som en forudsætning for, at læreren kan reflektere over og udvikle sin praksis, fordi læreren "aldrig kan forlade sig på rutiner, men bestandig må udøve dømmekraft" (Professsionsideal for Danmarks Lærerforening, 2021). Og for at "opfylde folkeskolens målsætning og undervisningsmål", som det lyder i det første punkt i professionsidealet, stilles der krav til "lærerens faglighed og selvstændige dømmekraft" (Professsionsideal for Danmarks Lærerforening, 2021). Dømmekraften og den professionelle udøvelse af den er med andre ord en kerne i lærergerningen.

Begrebet dømmekraft kender vi i filosofien fra Aristoteles over Kant, der som bekendt kaldte sin tredje kritik for Kritik der Urteilskraft, altså Kritik af 
dømmekraften, og frem til blandt andre Gadamer, der behandler begrebet i sit hovedværk, Wahrheit und Methode. Det er oplysende kort at se på begrebets udvikling i filosofien gennem disse tre nedslag, og hvordan de peger frem mod og bliver brugt $\mathrm{i}$ en bestemmelse af dømmekraften $\mathrm{i}$ en professionel kontekst. Hos Aristoteles er begrebet knyttet til phronesis, der er "orienteret mod det etiske" og "relateret til praksis" samt har "fokus på erfaringer og handling" (Haase, 2018, s. 81). Phronesis "kan forstås som en slags etisk-praktisk sans, der er retningsgiver for konkrete handlinger på baggrund af en værdianalyse" (Haase, 2018, s. 81), og det er ikke vanskeligt at se, hvordan man kan bruge begrebet til at beskrive den professionelles dømmekraft, der netop baserer sig på og tager retning af den praktiske og den etiske sans. Phronesis er "en handlekompetence til at gøre det gode og det rigtige på rette tid og sted" i situationer, "hvor valget af handling ikke gives entydigt" (Boll \& Nielsen, 2017, s. 1).

Kant ser den reflekterende "dømmekraft som mellemleddet mellem forstand og fornuft" og som en formidling "mellem teori og (moralsk) praksis" (Höffe, 1993, s. 222). Hos Kant indgår dømmekraften i undersøgelsen af sammenhængen mellem teoretisk og praktisk filosofi, ikke mindst i hans egen filosofi, især de to første kritikker. Dømmekraften er en tredje subjektiv evne, som uden at ophæve forskellen forbinder det teoretiske og det praktiske, og Kants definition af dømmekraften som "evnen til at tænke det særlige som indeholdt i det almene", men også som en dom, der skal "finde det almene til det givne særlige" (citeret efter Höffe, 1993, s. 222) er interessant i forhold til den professionelle dømmekraft. Bruger vi Kants bestemmelse i forhold til den professionelle dømmekraft, kan vi sige, at den professionelle, læreren, meget ofte må forbinde det særlige og det almene i en handlen.

Hans-Georg Gadamer er ganske konkret, når han skal udpege dømmekraftens betydning: "Hvad der adskiller tåben fra den kloge er, at han mangler dømmekraft, dvs. han formår ikke at subsumere og er derfor heller ikke i stand til på en hensigtsmæssig måde at anvende det, han har læst" (Gadamer 2004, s. 34). Gadamer kritiserer Kant for at fjerne begrebet fra sensus communis (den sunde sans eller den sunde fornuft), som det har været knyttet til, for i stedet at bruge det primært i forhold til den æstetiske dom, smagsdommen (Gadamer 2004, s. 34). Sensus communis knytter Gadamer til det at "kunne forstå og moralsk beherske den konkrete situation", og det vil også sige at kunne handle i den konkrete situation på baggrund af almene principper og erfaringen fra det konkrete" (Gadamer 2004, s. 30). Den konkrete situation er potentielt én i et utal af variationer, men i sig selv kalder den 
på forståelse. Gadamer kalder situationen hermeneutisk. Læreren må bruge (applicere) sin viden og erfaring og investere sin sunde fornuft og sit personlige ansvar i handlingen. Derfor er der grund til at interessere for udviklingen af læreruddannelsens praksisdimension, og der er grund til at være opmærksom på lærerens dømmekraft (Wiberg, 2014).

\section{Pinocchio i hvalfiskens bug}

I læreruddannelsen er der erfaringer med studieformer, der kan være ramme for en fokuseret og reflekteret omgang med empiri, fx skolebesøg under praktik, skoleovertagelse, praksissamarbejder, øvelses- eller universitetsskoleformater. Rammen kan skabes og udvikles der, hvor studerende, skolelærere, læreruddannere og evt. forskere undervejs i uddannelsen erfarer, analyserer og taler om betingelser, indhold og muligheder knyttet til den pædagogiske handling. Disse studieformer er det værd at opholde sig ved, og det er værd at udvikle dem, men først en historie fra det virkelige (skole)liv.

Under en praktik observerede en praktiklærer og en læreruddanner en lærerstuderende undervise i myter i en femte klasse. Den studerende lagde ud med frit at genfortælle historien om profeten Jonas, som Gud sendte til Nineveh for at profetere byens undergang. Jonas frygtede for rejsen, så han rejste i stedet væk med en båd, blev kastet over bord af sømændene og slugt af en hval. Efter tre dage i hvalens bug blev Jonas kastet op på land, hvorefter han tog til Nineveh og forkyndte byens undergang. Efter genfortællingen skrev den studerende MYTE på tavlen og bad eleverne komme med forslag til, hvad de forbandt med begrebet myte. Flere forslag kom på tavlen: 'en spændende historie', 'noget om gud eller guder', 'noget om gamle dage', 'fortiden', 'liv og død', 'Adam og Eva', 'skabelsen på syv dage'. På et tidspunkt foreslog en elev 'Pinocchio'. Den studerende affærdigede eleven og skrev ikke Pinocchio på tavlen ved siden af de andre forslag. Eleverne var blevet engagerede af den frie genfortælling. Mange kom med forslag. Der var pingpong. En stor del af eleverne i klassen bød ind, og den studerende fik tilvejebragt en ramme for det videre arbejde med myter.

I den efterfølgende samtale deltog tre parter: den studerende, skolens praktiklærer og en underviser fra læreruddannelsen. Formålet med samtalen er at etablere et rum for eftertanke over den undervisning, der lige har fundet sted. Indkredse situationer og give plads til refleksion, der ikke er plads til i aktionen, fordi det er lige nu og her, undervisningen sker. Det er 
ikke nemt, og det kan være sårbart. Derfor er der en opgave i at stilladsere samtalen, så den studerende får mulighed for at vende tilbage og gå undersøgende til de muligheder, der ligger i den gennemførte undervisning.

Samtalen åbnede for mange overvejelser, og afvisningen af forslaget om Pinocchio gav anledning til en interessant og afsøgende samtale. En samtale om samspil og spænding mellem elevers forforståelser og den studerendes faglige definition af mytebegrebet, om formålet med undervisningen, forholdet mellem religion, fiktion, litteratur og populærkultur. I samtalen forklarede den studerende, at forslaget i situationen forekom hende at være en afsporing af det, hun var i gang med at indkredse om myter gennem elevernes associationer. Eleven var ikke blevet spurgt, hvad han forbandt med Pinocchio, og det blev et tema i trepartssamtalen, der førte til en religionsfaglig og pædagogisk samtale, der rakte fra elevinddragelse til undervisning i myter. Afsættet var et 'Hvad nu hvis?' Hvad nu hvis eleven havde gode grunde til at foreslå Pinocchio? Trepartssamtalen bevægede sig, og den blev sin egen undervisningssituation, der inddrog teori i praksis.

Fra elevens perspektiv var forslaget sandsynligvis godt. Hovedpersonerne i de to fortællinger må begge opholde sig i bugen på en hval. De to fortællinger har med andre ord krisen i fortællingerne til fælles. Der er interessante forskelle mellem de to historiers grunde og årsager til udfrielsen, og disse forskelle er værd at undersøge, og de er værd at tale om. Den fortvivlede Jonas bliver kastet op på land, Pinocchio og hans far tænder bål og forårsager dermed selv deres udfrielse. Den studerendes mål var, at eleverne skulle lære noget om kristen mytologi. En brainstorm og elevens forslag åbnede for et perspektivskifte, analyse og justering på flere planer: mellem faglighed og elevernes referencerammer, motivation og det løfte, som et 'kom med det du tænker på' implicerer, mellem fiktion og religion, mellem fortælling og symbol og meget mere.

Man kan ikke bebrejde den studerende, at hun ikke griber referencen i situationen. Men det afgørende er, at man tilkender refleksionen over praksis opmærksomhed og giver den en form i læreruddannelsen, der kan stå mål med pædagogisk praksis som handling. Det er grunden til, at vi fremdrager eksemplet. Skal man, jf. den professionelle dømmekraft og at finde det almene til det givne særlige, uddrage en almen regel af eksemplet, som vi vender tilbage til, kunne et bud være, at man som lærer skal have en dialogisk indstilling (Dysthe, 1997). At man er autentisk lyttende, og at man forsøger at forstå, hvad eleven mener. Og at være dialogisk indstillet og 
autentisk lyttende kræver en solid dybdefaglighed, hvor man er så sikker i sit fag, at man kan slippe det planlagte - og lukke Pinocchio ind i klassen.

\section{Kernepraksis}

I amerikansk forskningslitteratur om læreruddannelse og praksis finder man begrebet kernepraksis (core practice). Begrebet rummer et bud på, hvordan man kan forstå samspillet mellem læreruddannelse og praktik, men også på, hvordan man kan forstå lærerstuderendes handlen og deres refleksion over forholdet mellem teori og praksis samt mellem viden og erfaring. Kernen er den empiri, som den studerende står med i en praksis. Begrebet kernepraksis er dog ikke et entydigt begreb. Derfor vil vi skitsere nogle karakteristika, som vi senere udfolder, ved at fokusere på empiribegrebet og praksis som en dialektik.

Pam Grossmann, Karen Hammerness og Morva McDonald argumenterer for at "teacher education should move away from a curriculum focused on what teachers need to know to a curriculum around core practice, in which knowledge, skill, and professional identity, are developed in the process of learning to practice" (Grossman et al., 2009, s. 274). Med artiklens argumentation flyttes fokus fra kompetencemål (curriculum) til en kompetenceforståelse, der har læreren eller den studerendes viden, færdigheder og læreridentitet som omdrejningspunktet for de kompetencer, der kendetegner professionen. Konsekvensen af forskydningen bliver, at praksis i udgangspunktet ikke defineres som kompetencer, som vi fx kender det i praktikken i dag, men som et tværgående felt mellem viden, færdigheder og læreridentitet.

At fokusere på kernepraksis stiller ifølge Grossmann et al. krav til både læreruddannere og praktiklærer om at kunne adressere undervisning som en kompleks udfordring og at kunne konkretisere praksis for lærerstuderende (Grossman et al., 2009, s. 277). I den forbindelse fremfører de en grundlæggende kritik af læreruddannelsen, som "generally [has] left coaching to field instructors [...], who provide field feedback during experience" (Grossman et al., 2009, s. 285). Det, de efterlyser i en kernepraksis, er et rum for frelles refleksion over den erfaring og den viden, som læreruddanneren, praktiklæreren og den studerende besidder med henblik på at udvikle og udfordre den lærerstuderendes viden, færdigheder og læreridentitet.

I en dansk kontekst påpeger Pia Böwadt i et udkast til en forskningsoversigt over en praksisnær læreruddannelse (2021), at et tættere samarbejde 
mellem skole og læreruddannelse eller læreruddannere, praktiklærere og studerende ikke i sig selv leder frem til bedre praksis. Hun påpeger, at distance til praksis er afgørende, når en kompleks praksis skal gøres til genstand for teoretisk refleksion. Med henvisning til von Oettingen og Elsebeth Jensen (2017) fremhæves det, at der i udviklingen af lærerprofessionen er brug for teoretisk distance til praksis. Det betyder, at kernepraksis ikke kun er en erfaring af og en fokusering på en given praksis, men også er en fokuseret teoretisk distancering, hvor en kompleks praksis sættes ind i en refleksiv konkretisering.

Flere studier beskæftiger sig med undervisning i og støtte af studerendes refleksive tænkning (fx Freese, 1999; Loughran, 1996). Begge studier beskæftiger sig med læreruddannelse, og de har fokus på at lære de studerende at reflektere gennem undervisning i, hvad refleksion er, og hvordan man konkret kan tænke og forholde sig refleksivt. Både Freese og Loughran bygger på Deweys og Donald A. Schöns idéer, fx Schöns skelnen mellem reflection-on-action og reflection-in-action (Schön, 1982). Loughran skelner mellem tre typer af refleksion, anticipatory reflection, retrospective reflection og contemporaneous reflection (Loughran, 1996, s. 102) og Freese beskriver Loughrans model som bestående af "reflection during the act of planning the lesson [...], and during the actual teaching of the lesson [...], as well as after the lesson" (Freese, 1999, s. 897). Disse tre dele hører alle naturligt med til en refleksiv konkretisering.

Her vil vi fokusere på Francesca M. Forzani, der foretager en kort historisk sammenligning mellem kernepraksis og andre praksisbaserede tilgange (Forzani, 2014, s. 357) og pointerer, at "although the phrase 'practice-based teacher education' abounds in policy documents, program descriptions, and other literature, there seems to be little consensus about what it means or should mean" (Forzani, 2014, s. 358). Det ligger lige for at antage, at fokus på praksistilgange og praksisforståelser på indholdssiden, som fx i de danske policypapirers fokus på mere praksis, bliver en åben og dermed også en flydende betegner.

Hos Forzani betegner begrebet kernepraksis den studerendes opnåelse af tekniske færdigheder, professionel dømmekraft og improvisatoriske evner. Det vil sige, at den studerende bevæger sig mellem på den ene side indstudering af rutiner og på den anden side improvisation og dømmekraft, som tager form gennem handlinger i en undervisningskontekst (Forzani, 2014, s. 366). Det vil sige, at praksis både indeholder en håndværksmæssig dimension bestående af metoder, tilgange, strukturer og en professionel 
dømmekraft, hvor håndværket udfordres gennem faglige, pædagogiske og didaktiske valg. Gennem erfaring - her refererer Forzani til Dewey opstår en improvisatorisk evne, hvor den studerende varierer håndværket og dømmekraften efter den undervisningskontekst, vedkommende befinder sig i. Når en elev ganske uventet bringer Pinocchio på banen, stiller det krav til den studerendes improvisatoriske evner, hvor denne skal bevæge sig i et samspil mellem håndværk, professionel dømmekraft, faglig viden og undervisningskontekst.

I arbejdet med kernepraksis påpeger Forzani, at praksis i en uddannelsesmæssig sammenhæng bør deles op i mindre dele, så man ser specifikt på fx gruppearbejde, elevers tænkning eller klassediskussioner, som derfra undersøges i dybden. Hun mener, som Grossmann, Hammerness \& McDonald, at kompleksiteten i praksis skal konkretiseres, for at den studerende kan undersøge egen og andres praksis fokuseret og reflekteret. Det er centralt, at praksis ikke reduceres til tekniske færdigheder, men at disse indgår i en samlet refleksion, hvor faglighed og didaktisk viden udvikler den professionelle dømmekraft og den improvisatoriske evne.

I forlængelse af Grossmann, Hammerness \& MacDonalds samt Forzani forstår vi ved kernepraksis følgende principper:

- Viden, færdighed og læreridentitet i praksis er centrale omdrejningspunkter

- Et samspil mellem erfaring og viden hos praktiklærer, læreruddanner og lærerstuderende finder sted, og det sker både i nær tilknytning til og på distance af praksis

- Praksis er en samtænkning af den håndværksmæssig dimension med professionel dømmekraft - herunder faglighed, pædagogik og læreridentitet - og improvisatoriske evner

- Akademisk indhold indgår som en nuancering og en udvidelse af erfaret praksis

- Der finder en konkretisering af praksis sted.

I en dansk kontekst har begrebet kernepraksis ikke vundet indpas. I et komparativt studie af læreruddannelsen i et globalt perspektiv (Weisdorf, 2020) opstiller Alan Klæbel Weisdorf i forlængelse af Darling-Hammond syv gennemgående træk ved eksemplariske læreruddannelser. Et af trækkene handler om at have et stærkt kerneindhold: "Et stærkt kerneindhold, som undervises i konteksten af praksis, og som er funderet på et videngrundlag om børn og elevers udvikling og læring og en forståelse for social og kul- 
turel kontekst, curriculum, evaluering samt fagdidaktik" (Weisdorf, 2020, s. 6). Weisdorf bruger ikke begrebet kernepraksis i rapporten, men taler i stedet om et kerneindhold, som han knytter til "konteksten af praksis", et psykologisk vidensgrundlag og en forståelse for kultur, curriculum og fagdidaktik. Weisdorf definerer ikke begrebet nærmere, men forståelsen af kerneindhold som sammenhængen mellem videngrundlag, forståelse og "konteksten af praksis" kan suppleres med Forzanis forståelse af kernepraksis som et forhold mellem tekniske færdigheder, professionel dømmekraft og improvisation (Forzani, 2014). Dermed rammer vi en grundforståelse af kernepraksis, hvor den studerende i konkrete praksissituationer skal reflektere over og udvikle egen lærerfaglige praksis og læreridentitet.

At karakterisere kernepraksis, som vi har gjort her, kender vi i praktikvirksomheden under betegnelsen praksissamarbejde. Her kan læreruddannelse inden for undervisningsfag og de pædagogiske fag sammen med praktikskolerne etablere undersøgelsesfællesskaber, fx i form af formaliserede samarbejder som UC Syds universitetsskolemodel (Oettingen \& Thorgård, 2019). Men er idéen om kernepraksis relevant for den formaliserede praktik? Hvis kernepraksis skal være relevant, kræver det en tættere tilknytning mellem undervisning og praktik (Slottved et al., 2019) og dermed et tættere bånd mellem akademisk og pædagogisk viden, praksisviden og erfaring (Grossmann et al., 2009), der kan udfordre den studerendes tekniske færdigheder og dømmekraft (Forzani, 2014).

Med kernepraksis som omdrejningspunkt er der fokus på, hvordan kvaliteten af praktikken og praksissamarbejdet kan styrke og udvikle den studerendes viden om og erfaring med praksis gennem tekniske færdigheder, dømmekraft og improvisation i en handlen $i$ og en distanceret teoretisk refleksion over praksis. I det følgende vil vi omsætte kernepraksis fra et begreb til en aktivitet, hvor forskellige aktører indgår i et undersøgende fællesskab. Aktiviteten beskriver vi som reflekteret omgang med empiri.

\section{Den dialektiske arbejdsform i empirisk analyse}

Vi har citeret Alexander von Oettingen for den påstand, at vi aldrig har haft flere empiriske data til rådighed end i dag, men, tilføjer han, det har øjensynligt ikke ført til nye bidrag til didaktisk og pædagogisk teori og heller ikke til en forbedret praksis i folkeskolen. Det skyldes, skriver han, at data er uden intentionalitet. Pædagogisk praksis er kendetegnet ved at være båret af intentionelle handlinger. Pædagogik er en nødvendig praksis, som 
skolelæreren forholder sig teoretisk til. Dette er det dobbelte grundforhold mellem teori og praksis.

I det følgende vil vi betragte von Oettingens udsagn som gyldigt og med baggrund i to påstande plædere for, at det ikke er mængden af empiriske data, der er afgørende for, om man kan reflektere kvalificeret over pædagogisk praksis i en læreruddannelsessammenhæng. Afsættet for vores forslag til analytisk arbejde med empiri i en pædagogisk praksis er, at data, forstået som løsrevet råstof, udenfor en pædagogisk sammenhæng ikke har værdi i forbindelse med undervisning. Omgang med empiri i en pædagogisk praksis vil altid være knyttet til en intenderet sammenhæng. Pædagogiske beslutninger og handlinger kan afdækkes og begrundes ud fra praktiske og teoretiske forhold afhængig af en pædagogisk, didaktisk situation. Pædagogiske beslutninger og handlinger kan gøres til empiri forstået som bidrag til at justere og rette konkret pædagogisk praksis såvel som empiri til udvikling af pædagogisk praksis mere generelt. Det kræver dog et særligt blik for og en særlig omgang med empiri.

Man kan anvende en fokuseret og retningsbestemt analyse og vurdering af udvalgt empiri fra undervisningssituationer, fx samtalen om Pinocchio, som afsæt for kvalitative justeringer af praksis. Og udvalgte teoretiske indfaldsvinkler til pædagogisk praksis skaber afsæt for eksperimentelle afprøvninger i undervisning - med særligt henblik på at være studerende ved en læreruddannelse. Vi vil i det følgende centrere os om tre begreber, teori, empiri og praksis, og redegøre for, hvordan begreberne forholder sig til hinanden i en dialektisk form. Undervejs vil vi inddrage praksiseksempler, og sidst i kapitlet vil vi præsentere en model til at kunne arbejde dialektisk i empirisk analyse.

\section{Reflekteret omgang med empiri}

Fred A. J. Korthagen udgav i 2001 sit hovedværk, Linking Practice to Theory. Korthagen tager udgangspunkt i betragtninger over læreruddannelsen i det hollandske uddannelsessystem, og her mener han at kunne se og redegøre for en bevægelse fra teori til praksis, hvor teori er direkte handleforeskrivende for praksis. Denne model kalder Korthagen en teknisk-rationel model. Modellen beskriver en kausal opfattelse af, at man kan implementere forsknings- og udviklingsviden (Teori med stort $T$ ) ved at gå ud i skolen og overføre den teoretiske viden til praksis. Korthagen beskriver processen således (vores oversættelse): "1. Teorier forbereder lærere til at handle med 
en hensigt [intentionelt] i deres profession, 2. De anvendte teorier skal være baseret på videnskabelig forskning, 3. Læreruddannere skal træffe valg i forhold til, hvilke teorier de anvender i læreruddannelsen" (Korthagen 2001, s. 3). Rationalet er, at læreruddannere overfører udvalgt forskningsviden til de lærerstuderende, som efter endt uddannelsesforløb tager ud i skolen og overfører den viden, som de har opbygget i løbet af deres studium, til en undervisningspraksis. Korthagen argumenterer (med henvisning til blandt andre Zeichner \& Tabachnick (1981)) for, at den konceptuelle viden, som de lærerstuderende oparbejder under uddannelse, hurtigt bliver glemt eller fortrængt ('washed out') til fordel for hverdagens praksisudfordringer. Korthagen skriver: "Even if student teachers rationally understand the importance of theory as a means to support practice, they soon experience that they are not the only ones struggling so much with everyday problems in their classrooms that the whole idea of applying theory becomes an impossible mission" (Korthagen, 2001, s. 5). Pointen er, at man i den teknisk-rationelle model har overset, at teori som forskrift for handling i den professionelle hverdag hurtigt taber overfor konkrete og praktiske udfordringer.

Korthagen foreslår derfor en alternativ model, hvor det er praksis, der er afsæt for teoretiske refleksioner. I refleksionerne anvender læreren eller den studerende i grupper teori (teori med lille $t$ ) til at ordne, systematisere og kategorisere praksiserfaringer. I analysearbejdet med praksiserfaringer opstår der ifølge Korthagen en internaliseret viden, som vil være direkte overførbar til praksis. Refleksioner og drøftelse over oplevede praksissituationer sammen med andre praksisudøvere vil bundfælde sig og efterfølgende medvirke til at kvalificere pædagogiske og didaktiske valg hos den udøvende lærer.

Hvor praksis i den teknisk-rationelle model ifølge Korthagen vil overtage og udvaske teoretisk refleksion, vil den alternative model kunne føre til øget professionel dømmekraft og handlekompetence. Reflekteret teoretisk omgang med udvalgte praksiserfaringer (empiri) kræver tid og distance fra praksis for at kunne afdække tilstrækkelige kvalificerede alternative handlemuligheder. Korthagen gør den alternative model til afsæt for en ny uddannelsestænkning, som han kalder 'A Realistic Teacher Education'.

I Pinocchio-eksemplet vælger den lærerstuderende at overhøre elevens forslag og begrunder sin beslutning med, at inddragelse af den intertekstuelle reference vil føre til en afsporing af den oprindelige lektionsplan. Lektionsplanen har ganske givet været udarbejdet efter alle didaktiske forskrifter. Men i forhold til (i hvert fald) to af principperne for kernepraksis, så formår 
den studerende ikke at opfylde kravene. Det første princip er, at viden, færdigheder og læreridentitet i praksis er centrale omdrejningspunkter. Eksemplet viser, at den studerende ikke har et tilstrækkeligt overblik over det tekstunivers og de fortællinger, der kan knytte an til myten om profeten Jonas. Her vil mere praksis og flere erfaringer fra undervisning ikke være et tilstrækkeligt grundlag at reflektere over situationen med. Det kræver et fagligt overblik at kunne gribe elevens input og omsætte det og integrere det $i$ undervisningen som et velvalgt og relevant perspektiv. I eksemplet ser vi en praksis der ikke formår at gribe den didaktiske mulighed i øjeblikket. Man kan naturligvis ikke forlange at en studerende eller en lærer kan vide alt eller fange ethvert input fra eleverne, men man kan stille krav om lydhørhed og nysgerrighed i forhold til et perspektiv, en elev bringer frem. Det vil man i en refleksion over situationen med fordel kunne fokusere på, for at den lærerstuderende kan aktivere princippet om at samtænke praktiske færdigheder med dømmekraft og improvisatoriske evner. På den vis ville det have været muligt at inddrage og værdsætte elevens input og vise professionelt mod og dømmekraft ved at turde følge det overraskende input. I Korthagens alternative model kunne Pinocchio-eksemplet som en udvalgt situation være afsæt for en reflekteret omgang med teori og praksis i samtale mellem praktiklæreren, læreruddanneren og den lærerstuderende.

\section{Dialektisk omgang med empiri}

I "Pædagogisk forskning mellem teori, empiri og praksis" argumenterer Alexander von Oettingen for en struktur, hvor empirisk arbejde deles i to forskelligartede og forskelligt rettede fremgangsmåder. Inspireret af Dietrich Benner skelner han mellem på den ene side praktisk empiri og på den anden side teoretisk empiri.

Om forholdet mellem empiri og praksis skriver von Oettingen: "Data [ubehandlet empiri] er fri for intentionalitet og dermed også ansvar. Det er lærerens ansvarlige handlinger, hvor han eller hun dømmer og bedømmer, der er afgørende for en forbedret praksis" (von Oettingen, 2018, s.57). Empiri skal her forstås som en genstand for en anskuelsesform, hvor en professionel eller en studerende ser på et udsnit af praksis med det formål og den rettethed 'at blive en pædagogisk erfaring klogere'. Man må spørge, hvordan et udsnit af praksis kan kvalificeres, så det kan blive empirisk kvalificeret ind i en pædagogisk praksis? Det kan det, ved at en lærer eller lærerstuderende opfanger, at der er et brud, en udfordring eller en problemstilling i praksis, 
som kan indfanges og gribes pædagogisk. Det efterfølgende analysearbejde med empiri har til formål at reflektere over, drøfte og afdække og afprøve alternative handleforslag til undervisning. Analysearbejdet i forholdet mellem praksis og empiri har en dialektisk struktur, hvor praktiske erfaringer fra undervisning sættes i sammenhæng med faglige, pædagogisk-didaktiske og relationelle kategorier. Der reflekteres og sammenlignes med andre og tidligere erfaringer, og det drøftes, hvilke faglige og pædagogiske potentialer situationen rummer. Dialektiske drøftelser af empirisk materiale i en praktisk pædagogisk sammenhæng vil ofte have form af: 'Næste gang, jeg står i en lignende situation, overvejer jeg i stedet...', 'Omvendt kan jeg også gøre...' eller 'Havde du i stedet valgt at...'. I denne form for dialektisk arbejde mellem empiri og praksis er erkendelserne betinget af praksis og forpligtet på at blive omsat tilbage i en pædagogisk praksis.

Om forholdet mellem empiri og teori skriver von Oettingen: "Empirien afprøver de teoretiske hypoteser og antagelser - ikke som en kausal verifikation eller falsifikation, men via eksperimentel vekselvirkning mellem teoretisk og empirisk viden. Der etableres et dialektisk forhold mellem empiri som det medierede og fokuserede udsnit af praksis og den om-gribende teori. Empiri er kanal for og indgang til et teoretisk blik på praksis - men empiri er samtidig trykprøver for teoriens samspil med praksis" (von Oettingen, 2018, s. 47). I denne type empirisk arbejde har teorien forrang for det praktiske udfald. Det betyder, at læreren eller den lærerstuderende fortsat skal være rettet mod og tage hensyn til elevernes faglige udbytte af undervisningen, samtidig med at de afprøver udvalgte teorier og metoder i praksis. Det er væsentligt, at man har blik for, hvilke potentialer forskellige fagdidaktiske eller pædagogiske teorier har i en undervisningssammenhæng. Udvalgt og fokuseret teoretisk arbejde med empiri kan være med til at definere det undervisningsindhold, udvalget af materialer, rammer og samarbejdsformer, der skal udfolde sig i praksis. Arbejdet med empiri har ikke til hensigt at løse problemer fra praksis, men at udfordre praksis med eksperimentel omgang med teori overført til praksis. I denne type fokuseret analytisk omgang med empiri skal teorien afprøve grænser, eksperimentere med og udvikle praksis. Dialektiske drøftelser af udvalgte teoretiske afsæt afprøvet på praksis vil ofte have form af 'På den ene side ... på den anden side', 'Du kan også vælge at anskue problemstillingen fra et andet perspektiv' og 'Kan den erfaring overføres til lignende situationer'. Intentionen er at løfte blikket fra de enkelte praksissekvenser og forsøge at begribe dem med mere generaliserbare termer. 
I nedenstående figur forsøger vi at imødekomme Korthagens beskrivelse og kritik af den teknisk-rationelle model. Ikke ved at forsvare modellen eller forståelsen af, at Teori kan overføres til praksis i et direkte kausalt forhold, men ved at lade teori udfordre eksisterende praksis ved at foretage eksperimenterende afprøvninger i undervisningen med det formål at udvikle praksis.

Omvendt vil en løbende analytisk-reflektorisk omgang med praksiserfaringer altid være en integreret del af professionelt arbejde med undervisning. Formålet er at indsamle og se på empirien med henblik på at justere beslutninger og valg i praksis. Teori er afsæt for at afprøve eksperimenterende tiltag i undervisningen med det formål at udvikle praksis og afprøve teoriernes anvendelighed. Figuren skal vise, at teori og praksis ikke består som et modsætningsforhold, men indgår i et samspil omkring reflekteret omgang med empiri.

Figur 1. Dialektik, inspireret af von Oettingens ideer om forholdet mellem teori, empiri og praksis. Analysearbejde beskrives som to dialektiske bevxgelser med to forskellige hensigter og formål.
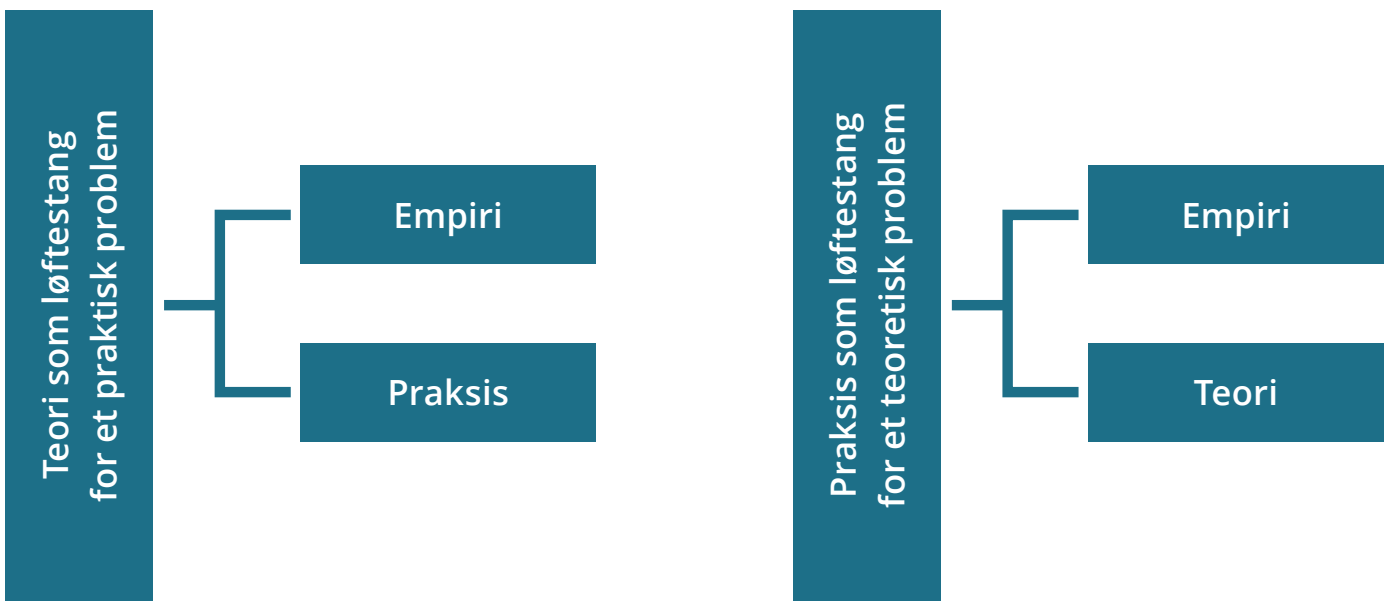

\section{Undersøgelsesfællesskaber}

Som ramme for en fokuseret, dialektisk og reflekteret omgang med empiri stiller undersøgelsesfællesskaber et mulighedsrum op, hvor empiri kan undersøges og udfordres gennem viden og erfaring og dermed bevæge sig i retning af såvel en teoretisk forståelse som en praktisk udvikling af faglige og didaktiske handlemuligheder. Dermed bliver undersøgelsesfællesskaber til potentialer, hvor teori og praksis ikke er modsætninger, men mulighedsrum for udfordring af teoretiske positioner og lærerfaglig dømmekraft. 
Man kan i undersøgelsesfællesskabet omgås empiri dialektisk, hvor empiri i denne sammenhæng er udvalgte oplevelser, erfaringer og situationer fra en pædagogisk praksis. Empirien udvælges på baggrund af faglige, pædagogiske, didaktiske, relationelle områder eller fra andre felter hentet fra undervisningsverdenen. Empirien er interessant fordi den afføder spørgsmål til valg og handlinger i en undervisningspraksis. Det kan være opdagelse af 'brud', 'oversete muligheder', 'konfrontationer' m.m.

Man kan indsamle empiri på mange måder. I vores fremstilling af reflekteret omgang med empiri i undersøgelsesfællesskaber er det eksemplet som en praksisfortælling eller en undervisningsobservation med udvalgte fokusområder - som er særligt interessant. Den type empiri giver substans og kropslighed til situationerne, og den er ofte forankret som oplevelser og erfaringer hos en eller flere aktører. Empirien gøres til genstand for en reflekteret drøftelse mellem henholdsvis læreruddanner- og lærerperspektiv samt den studerendes erfaringer. Vekselvirkning mellem at opbygge viden, afprøve og øve sig i praksis samt være en del af et undersøgelsesfællesskab er at arbejde i og med kernepraksis. Processen er fortløbende og gevinsten i samarbejdet er ikke forbeholdt den studerende, men i lige så høj grad læreren og læreruddanneren.

Undersøgelsesfællesskaber er ikke i sig selv garanti for refleksion. Studiet af Francis et al. (1999) viser, at undervisning i refleksion skaber sammenhæng mellem teori og praksis ved at forbedre kvaliteten af studerendes refleksioner. Endvidere viser studiet, at hvis de studerende ikke først har lært at reflektere på de lavere niveauer, dvs. med fokus på de praktiske og tekniske aspekter af praksis, kan de ikke reflektere på det højeste niveau, som i dette tilfælde er kritisk refleksion.

Det kræver erfaring og facilitering. Derfor kan deltagelsen i undersøgelsesfællesskaber være en nødvendig og løbende del af den studerendes udvikling fra afprøvende novice til reflekterende praktiker. Med denne argumentation kan vi tale for, at styrkelse af refleksionen omkring praksis netop sker gennem praksissamarbejdet. Det kan give god mening at tale om mere praksis eller praktik i læreruddannelsen, men endnu vigtigere er drøftelse af, hvordan kvaliteten af praksiserfaringer sikres. Undersøgelsesfællesskaber kan i den sammenhæng være ét bud på en samarbejdsform som kvalificerer praksiserfaringer.

Undervisning er et flygtigt fænomen, men måske kan undersøgelsesfællesskabet vænne den studerende til at fastholde, tale om og reflektere over undervisning og didaktiske valg. Den professionelle dømmekraft og hen- 
sigtsmæssige handlinger beror på komplekse forhold - herunder moralsk indsigt, erfaring med praksis og teoretisk indsigt. Undersøgelsesfællesskaber er én måde at arbejde bevidst med perspektiver fra praksis og fra uddannelse. Pinocchio-situationen rummer pædagogiske potentialer for reflekteret og fokuseret omgang med empiri med henblik på at sætte viden, didaktik og erfaring i spil. Det er et eksempel, der understreger muligheden for og kvaliteten i en fokuseret omgang med empiri, hvor læreren, læreruddanneren og den studerende udgør et undersøgende fællesskab. Udfordringen er at gøre disse fællesskaber til en central del af de studerendes forløb på læreruddannelsen, så de gør sig erfaringer med fokuseret og reflekteret omgang med empiri inden for undervisningsfag, pædagogiske fag, praktik og på tværs af de tre områder.

Jenset, Klette \& Hammerness peger på internationale tendenser i denne retning. De nævner fx "teacher training schools in Finland [...] university schools in Norway [...] and professional development schools in the United States" som eksempler på eksplicitte partnerskaber mellem læreruddannelser og skoler i udviklingen af praksis (Jenset et al., 2018, s. 185). Ser vi på professionshøjskolerne, er der allerede bud på undersøgelsesfællesskaber i sådanne partnerskaber. På VIA har man længerevarende erfaringer med Teaching Lab. Senere har man fokuseret på praktikkens trepartssamtale gennem uddannelseslaboratorium for god undervisning og uddannelse. I UC Syd har man Universitetsskolen som en grundlæggende sammentænkning af forskning, læreruddannelse og skoleudvikling (Oettingen \& Thorgård, 2019). Det kan være veje at gå.

\section{Referencer}

Benner, D. (1980). Das Theorie-Praxis-Problem in der Erziehungswissenschaft und die Frage nach Prinzipien paedagogischen Denkens und Handlens. Zeitschrift für Pädagogik, 26(4), 485-497.

Boll, B., \& Nielsen, L. (2017). Introduktion til begrebet dømmekraft. UCN.

Böwadt, P. R. (2021). En mere praksisnær læreruddannelse? Udkast til en forskningsoversigt. Københavns Professionshøjskole.

Danmarks Lærerforenings folkeskoleideal. https://www.dlf.org/media/12993193/folkeskoleideal_fuld_version_.pdf

Dysthe, O. (1997). Det flerstemmige klasserum. Klim.

Forzani, F. M. (2014). Understanding 'Core Practices' and 'Practice-Based' Teacher Education: Learning from the Past. Journal of Teacher Education, 65(4), 357-368.

Freese, A. R. (1999). The role of reflection on preservice teachers' development in the context of a professional devel-opment school. Teaching and Teacher Education, 15, 895-909.

Frostholm, C. Y. (2018). Træmuseet. Politisk Revy.

Gadamer, H.-G. (2004). Sandhed og metode. Systime. 
Grossman, P., Hammerness, K., \& McDonald, M. (2009). Redefining teaching, re-imagining teacher education. Teachers and Teaching, 15(2), 273-289.

Höffe, O. (1993). Immanuel Kant. I: Jensen, K. K., Filosofi. Nyere tid fra Bacon til Nietsche (s. 196-228). Politikens Forlag.

Haase, S. (2018). Den skønnede evidens. Tidsskrift for professionsstudier, 26, 74-84.

Jenset, I. S. (2018). Researching pratice-based teacher education. Acta Didactica, 12(3).

Jenset, I. S., Klette, K., \& Hammerness, K. (2018). Grounding Teacher Education in Practice Around the World. Journal of Teacher Education, 69(2), 184-197.

Korthagen, F. A. (2001). Linking Practice and Theory. Routledge.

Loughran, J. (1996). Developing Reflective Pratice. Falmer Press.

Oettingen, A. v. (2018). Pædagogisk forskning mellem teori, empiri og praksis. I: Oettingen, A. v., Empirisk dannelsesforskning (s. 19-62). Hans Reitzels Forlag.

Oettingen, A. v., \& Thorgård, K. (2019). Universitetsskolen. Dafolo.

Professsionsideal for Danmarks Lærerforening. https://www.dlf.org/media/7656831/profesionsideal_endelige-version.pdf

Schön, D. A. (1982). The Reflective Practioner. Basic Books.

Slottved, M., Foged, S. K., \& Nøhr, K. (2019). Læreruddannelse i et internationalt perspektiv. En litteraturkortlægning. VIVE.

Uddannelses- og Forsknngsministeriet (14. august 2020). Læreruddannelsen skal tættere på praksis. https://ufm.dk/aktuelt/pressemeddelelser/2020/laereruddannelsen-skal-taettere-pa-praksis

Uddannelses- og Forsknngsministeriet (27. november 2020). Minister sætter gang $i$ arbejdet med at udvikle læreruddannelsen. https://ufm.dk/aktuelt/pressemeddelelser/2020/minister-saetter-gang-i-arbejdet-med-at-udvikle-laereruddannelsen

Uddannelses- og Forsknngsministeriet (27. november 2020). Nytænkning af læreruddannelsen. https://ufm.dk/aktuelt/pressemeddelelser/2020/filer/notat-om-udvikling-af-laereruddannelsen.pdf

Weisdorf, A. K. (2020). Læreruddannelsen i et globalt perspektiv. Danske Professionshøjskoler. Wiberg, M. (2014). Evidence-based Methods and Conforming Judgemant. Cursiv, 14, 51-65. 